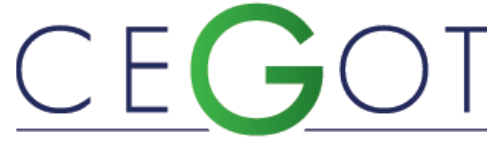

Centro de Estudos de Geografia e Ordenamento do Território
EL Motaki, HANIFA

Laboratory, Environment, Development and Spatial Management. Department of Geography, University Ibn Tofail

University Ibn Tofail, 14000 Kenitra. Morocco

elmotakihanifa@gmail.com

\section{EL-Fengour, ABDELHAK}

Laboratory, Environment, Development and

Spatial Management. Department of Geography, University Ibn

Tofail

14000 Kenitra. Morocco

elfengourabdo@gmail.com

EL BouzIDI, AISSA

Laboratory, Environment, Development and

Spatial Management. Department of Geography, University Ibn

Tofai

14000 Kenitra. Morocco

elbouzidiaissa@yahoo.fr

Madureira, Helena

Department of Geography, Faculty of Arts. University of Porto.

Portugal / CEGOT

4150-564, Porto, Portugal

hmadureira@letras.up.pt

Monteiro, ANA

Department of Geography, Faculty of Arts. University of Porto.

Portugal / CEGOT / ISPUP-CITTA

4150-564, Porto, Portugal

anamonteirosousa@gmail.com

\title{
The global change impacts on forest natural resources in Central Rif Mountains in northern Morocco: extensive exploration and planning perspective
}

Os impactes das mudanças globais nos recursos florestais na área de montanha do Rif Central em Marrocos: da exploração extensiva às perspetivas de planeamento

Referência: xxx (2019). The global change impacts on forest natural resources in Central Rif Mountains in northern Morocco: extensive exploration and planning perspective. Revista de Geografia e Ordenamento do Território (GOT), n. ${ }^{\circ} 17$ (junho). Centro de Estudos de Geografia e Ordenamento do Território, p. 75-92, dx.doi.org/10.17127/got/2019.17.004

\section{ABSTRACT}

The global changes including social, environment and economic transformation constitute a major handicap to the sustainable development of the Moroccan Central Rif mountains area. The accelerated degradation of the forest resources in this area demonstrates that there is a dynamic interaction between the biosphere and community groups.

These ever-changing interactions between the need to live and the limited of natural environment skills, give rise to environments that have been developed, built or, in general, altered or degraded. The available statistical data, cartography, field surveys and visits have 
shown a regression of forest superficies in the profits of the new types of illegal farming, despite the national and international development programs had established since the 1960s.

Keywords: Global change; Forest; Central Rif Mountains; Planning.

\section{RESUMO}

As mudanças globais, incluindo a transformação social, ambiental e económica, constituem uma grande desvantagem para o desenvolvimento sustentável da área de montanha do Rif Central, Marrocos. A degradação acelerada dos recursos florestais nesta área demonstra que há uma interação dinâmica entre a biosfera e os grupos comunitários.

Estas interações, em constante mudança, entre as necessidades quotidianas e as limitadas capacidades do ambiente natural dão origem a meios que têm vindo a ser desenvolvidos, construídos ou, em geral, alterados ou degradados. Os dados disponíveis, estatísticos cartográficos, de levantamentos de campo e visitas mostraram uma regressão das superficies florestais a favor de novos tipos de agricultura ilegal, apesar dos programas nacionais e internacionais de desenvolvimento estabelecidos desde a década de 1960.

Palavras-chave: mudança global; Floresta; Montanhas Rif Central; Planeamento.

\section{Introduction}

The conservation of forest natural resources in northern Morocco is a complex problem. The heterogeneity of the physical context and the anthropogenic uses and pressures practiced by the various stakeholders, are general rule in the Mediterranean for millennia (Quézel, P. and Médail, F., 2003). The natural environment in the Central Rif in northern Morocco area is rich but threatened by overexploitation and degradation of forests. The agricultural land and water resources are strongly degraded; mainly due to the local natural environment, and human intervention at a later stage.

The fragility of the geological formation and the irregular and often violent precipitation favourite the degradation of forest natural resources in the Rif mountain area. The dominance of marl lithology and the high degree of slopes aggravate the degradation phenomenon process. The vegetation cover is reduced because of the anthropic action and the environment conditions, as a result, the soil is poorly protected in the arid and semi-arid zones in the Rif and Prerif of our study area. Thus, the degradation of forest natural resources is important either on slopes or in alluvial zones. 
The objective of this paper is to demonstrate what are the most factors impact the forest natural resources, and, in second step, the paper aims at analysing the outcome of the dynamics through forms and processes of the evolution and the degradation of forest natural resources in Central Rif Mountains in northern Morocco.

\section{Study area}

The study area located in Northern Morocco, bounded to the North by the Mediterranean Sea, to the south by the Prerif zone, in the Western part is limited by the Western Rif and to the east by the Eastern Rif (fig. 1). This division was designed by several researchers based on different criteria and especially the geological structure (Asebriy, L. et al., 1987; Maurer, G., 1968).

The Central Rif is undoubtedly the region most affected by various types of degradation. These phenomena, which have a considerable impact on the natural environment, are also the major and permanent threat to the environment and the society.

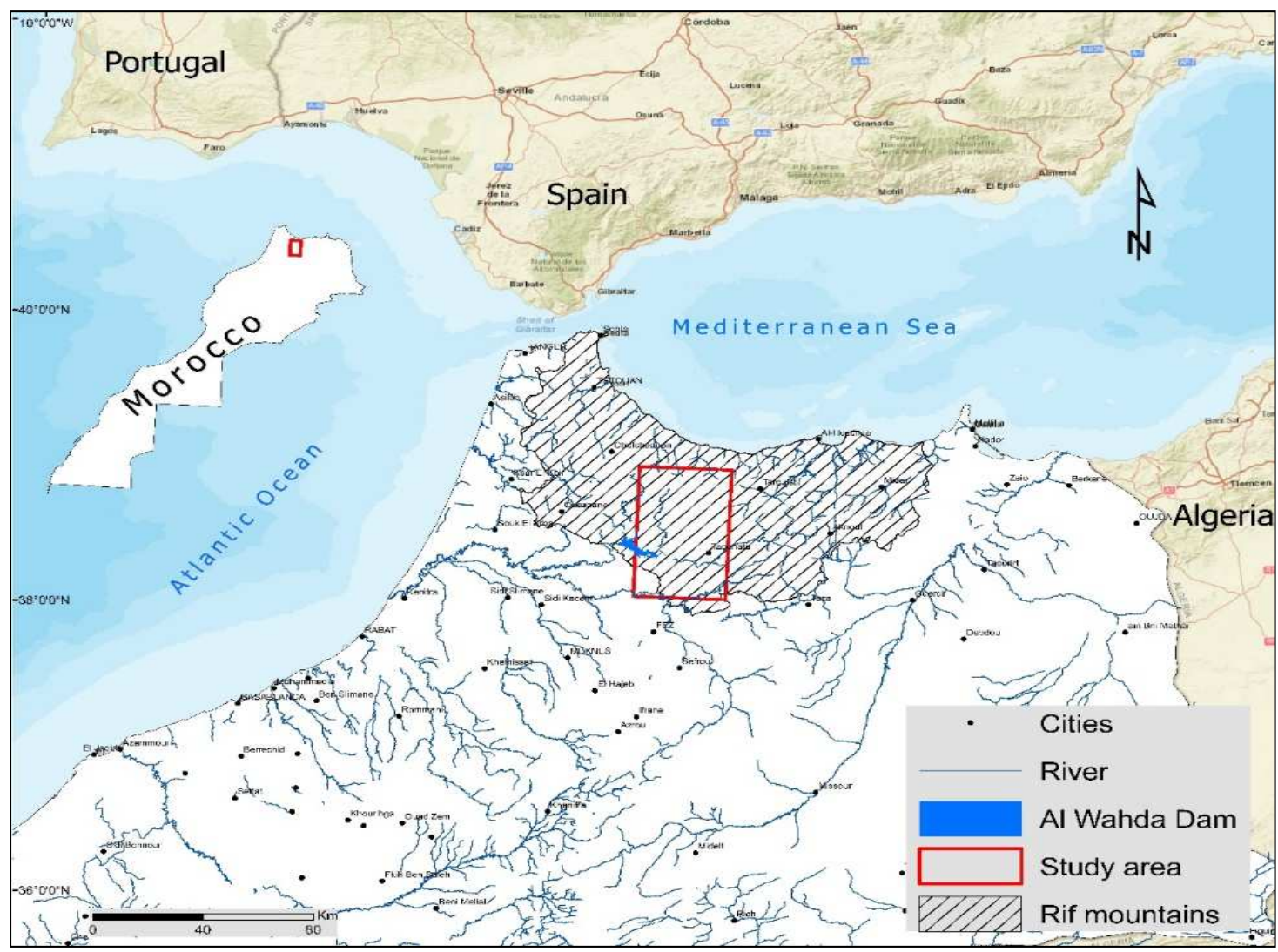

Figure 1 - Localization of the study area in northern Morocco. 


\section{Geodynamic settings and environmental constraints of the study area}

The Central Rif area is very vulnerable to the degradation of natural environments, as it is characterized by a regression of its protective vegetative cover combined with steep slopes, the predominance of friable lithological formations (marl, marl-limestone and shale) and abundant rainfall.

\subsection{Friable lithological formation}

The Rif mountain chain constituting the southern branch of the Gibraltar arch borders of the Alboran basin (SW of the Western Mediterranean). The current evolution is complex and results from multiple orogenic processes (burial, exhumation and rifting), In relation with the convergence between the Eurasian and African lithospheric plates (Andrieux, J., 1971).

The study area of Central Rif mountain is divided into three big geological categories (Asebriy, L. et al., 1987; Maurer, G., 1968). In the Northern part, we find the Intrarif zone in direct contact with the flysch zone limited by Mediterranean Sea, in the southern part there is the Prerif area and in the middle, part the Mesorif domain (Fig. 2).

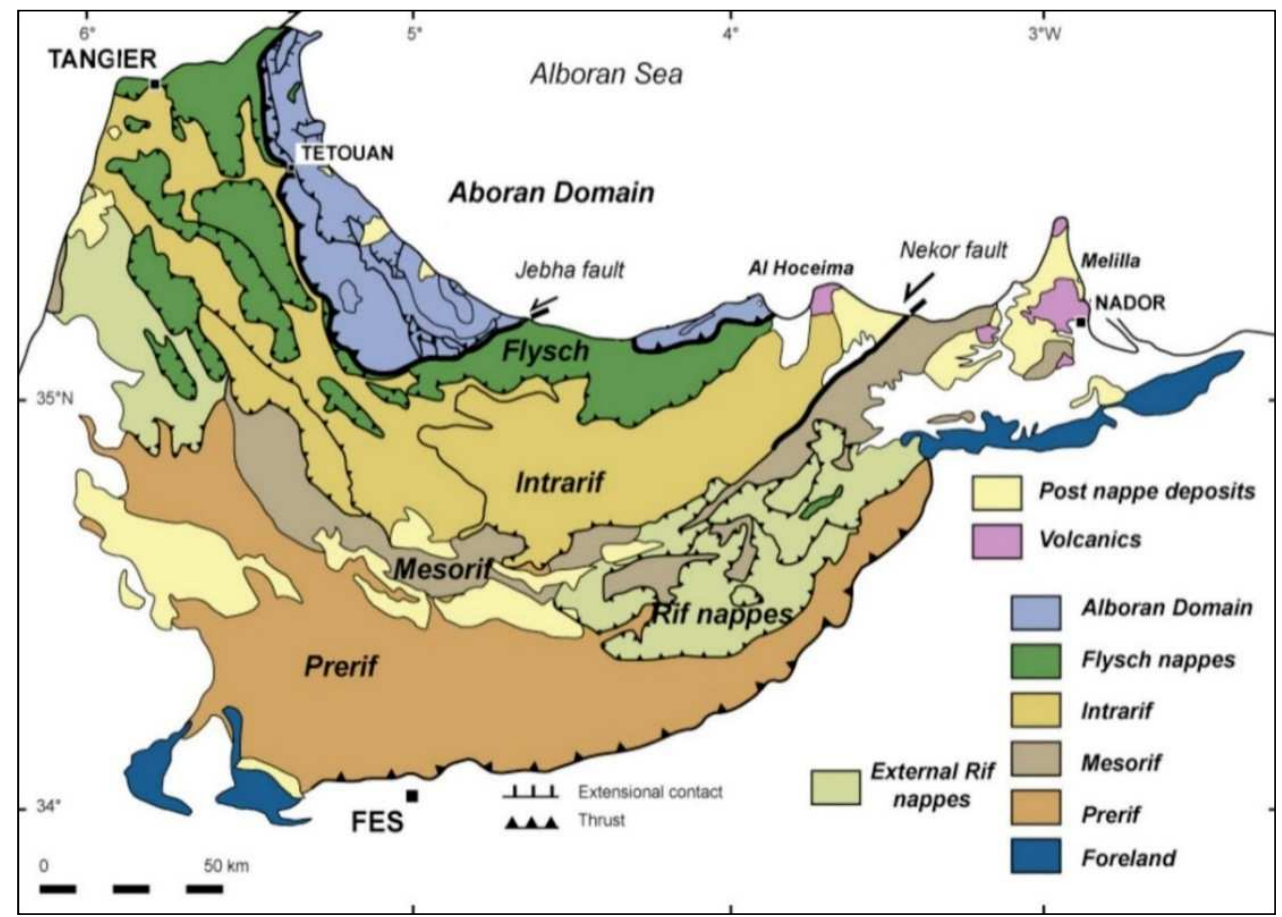

Figure 2 - Geological structure of Central Rif mountain (Extracted and adapted from Suter, G. and Mattauer, R., 1964) 
- Intrarif consists of Ketama unit appears in the Central Rif and affected by two schistosity phases and two metamorphism phases. The first phase is of upper Oligocene and lower Miocene, and the second of Upper Miocene (De Lamotte, D. F. et al., 1991). Tangier unit: is a little deformed, it is considered as the cover of the Ketama unit, with a stratigraphic series from the Cenomanian to the inferior Miocene, However, it is symbolized by clay marls of the Upper Cretaceous. Loukkos unit: is a zone of tectonic scales, which has flush in the Western front of the Tangier unit. These facies are of age ranging from the Albo-Aptian to the Eocene (Benyaich, A., 1991; Lespinasse, P., 1975).

- Mesorif is also named window areas, is characterized by a set of antiforms, whose hearts consist of formations from the lower to middle Miocene Overlapped by allochthones and pleated Mesozoic layers (Durand-Delga, M. et al., 1960).

This current structure has been interpreted as:

- The African Jurassic-Cretaceous passive margin that had undergone a tectonic inversion and would have formed the Miocene Mesorif structure zone (Benzaggagh, M. et al., 2014).

- A block of the Tell margin -Algeria) that would had displaced about $250 \mathrm{~km}$ westward to the Upper Oligocene-Miocene due to a major movement transforming fault and oblique to the paleo-mark, named Oran-Mesorif Strike Slip Fault (Benzaggagh, M. et al., 2014).

- Prerif is dominated by Jurassic and Cretaceous formations, the same as Mesorif domain, are represented by three different series (Wildi, W., 1981):

- A thick formation of flysch.

- A limestone series, forming the Sofs line.

- An alternating series with dominant of marl formations.

These lithological materials are very friable and have a very high sensitivity to climatic variations.

\subsection{Climate: a generator factor of forest degradation}

The Rif Central Mountain is subjected to Mediterranean influence in the North, oceanic in the West and exposed to the continental air masse impacts in the centre. The available rainfall data shows that the quantity rises in parallel with the altitude from the hills of the 
Prerif in the south to the Rif mountains in the north of the study area toward the Mediterranean Sea. The rainfall annual average of the study area varies between 600 $\mathrm{mm} /$ year and $1500 \mathrm{~mm} /$ year (Table 1).

\begin{tabular}{lccccc}
$\begin{array}{l}\text { Climatic } \\
\text { Station }\end{array}$ & $\begin{array}{c}\mathbf{X} \\
\text { Latitude }\end{array}$ & $\begin{array}{c}\mathbf{Y} \\
\text { Longitude }\end{array}$ & $\begin{array}{c}\text { Z } \\
\text { Height in } \mathbf{~}\end{array}$ & Serie & $\begin{array}{c}\text { Annual average in } \\
\mathbf{m m}\end{array}$ \\
\hline Jbel Oudka & 551000 & 461000 & 1115 & -1979 & 1472 \\
\hline \multirow{2}{*}{ Galaz } & 555320 & 439850 & 214 & -1980 & 654 \\
\hline & & & & 2013 & \\
\hline Ratba & 542890 & 464240 & 700 & -1999 & 950 \\
\hline
\end{tabular}

Table - 1 Characteristics of climatic stations in Central Rif Mountain area (ABHS, 2014).

The variability of the annual rainfall in the study area reached more than $100 \%$ between the two stations localized in two extremes borders of the study zone (Fig. 3 and 4).

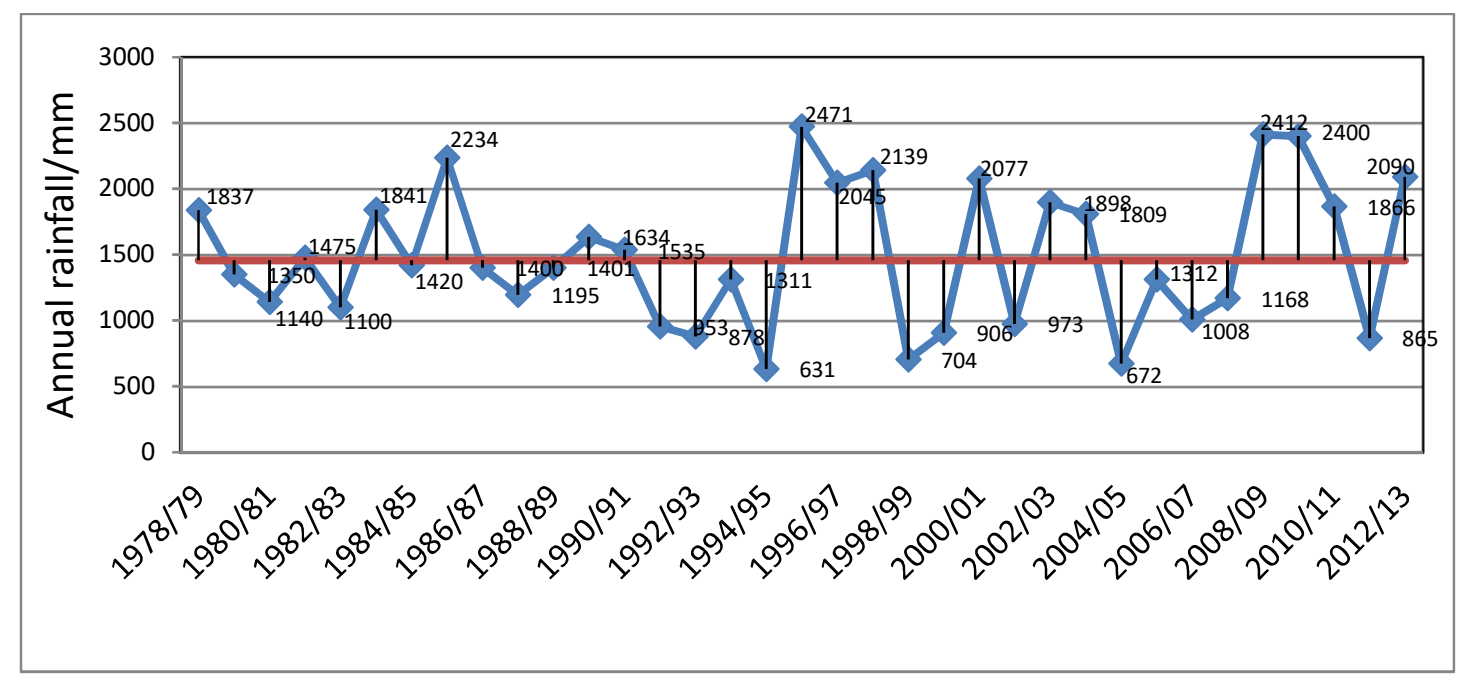

Figure 3 - Variability of the annual rainfall at Jebel Oudka climatic station in the North of the study area. 


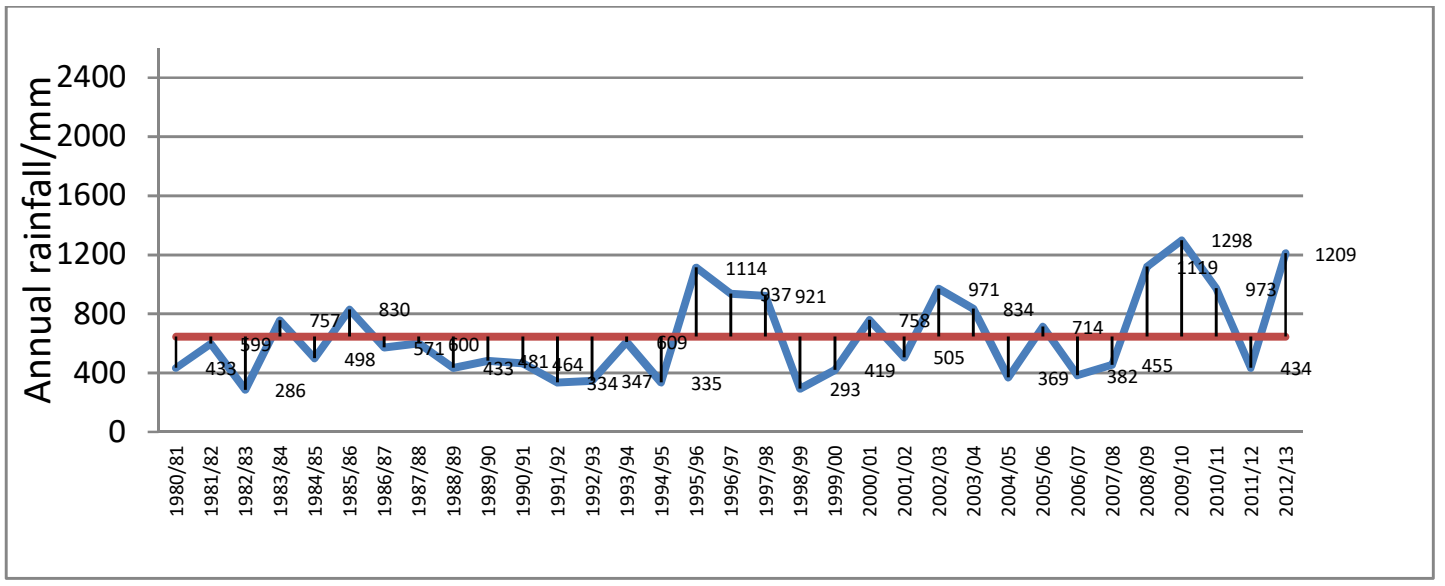

Figure 4 - Variability of the annual rainfall at Galaz climatic station in the south of the study area.

The lowest values of the precipitation are observed in the southern zone and more precisely in the Prerif (286mm in 1982-1983), on the other hand the highest values are observed in the heart of the Rif chain (2471 in 1996-1997), particularly at Jbel Oudka station, where the precipitation exceeded $1500 \mathrm{~mm} /$ year.

This statistical study series show that the coefficient of variation of annual rainfall generally increases from the south to the north. It is strongly influenced by relief nature and for some period the rate of change exceeds $22 \%$.

\subsection{Relief and morphology}

The objective of the analysis of these parameters is to characterize the factors of the degradation of the environment, natural resources and the topographic factor remains the most relevant. The relief plays a very important role in the spatial distribution of precipitation and highlights the influence of altitude, and consequently aggravates and / or reduces the risk of deterioration of forest natural resources depending on surface morphology (Fig. 5).

The altitude of the study area varies between $76 \mathrm{~m}$ in the bottom of the Ouerrha valley and the summit of the Tidrine mountain in which the altitude reached $2456 \mathrm{~m}$. Based on the available data, the distribution of the relief has a relevant influence on the rainfall quantities. 


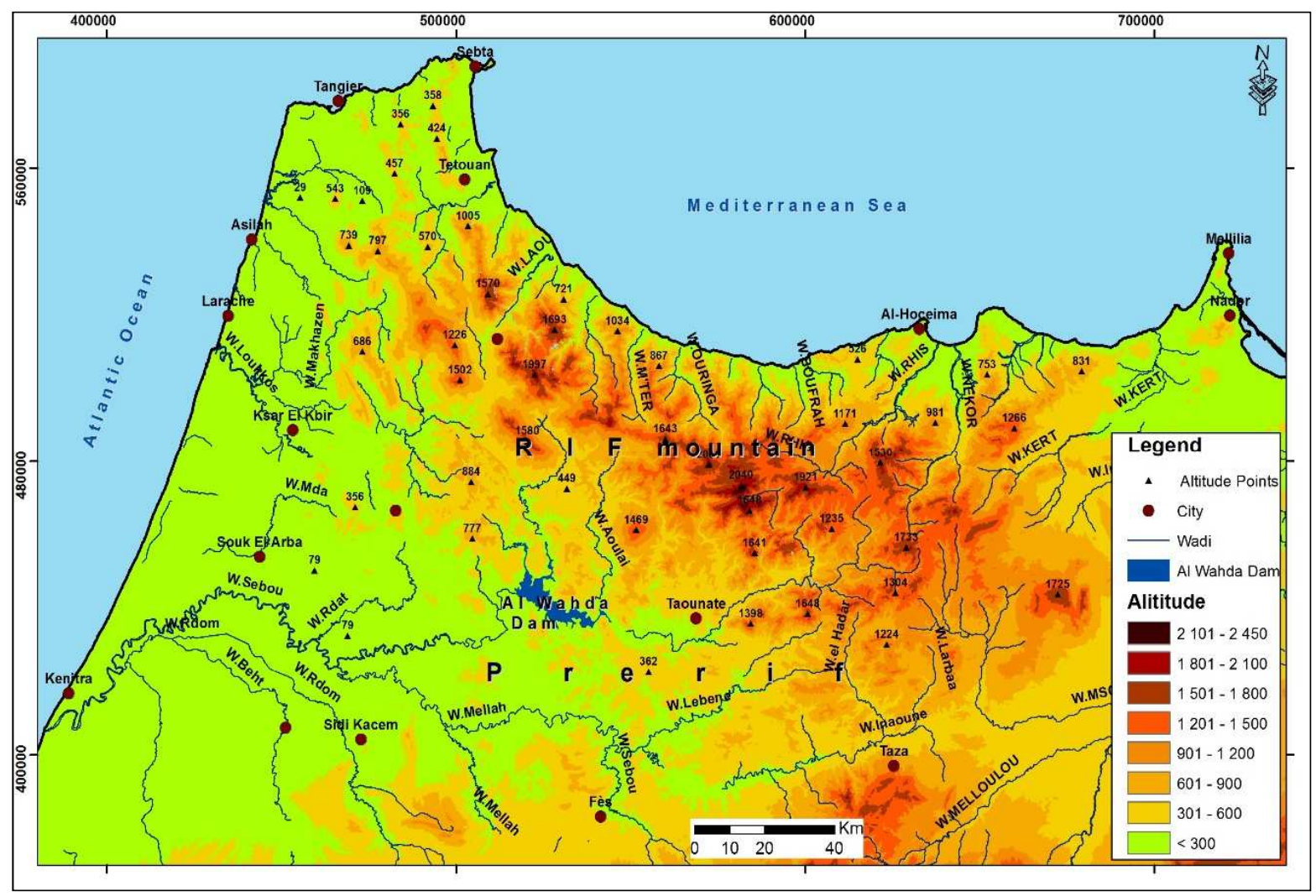

Figure 5 - Distribution of altimetric levels in the study area in Northern Morocco.

\section{Degradation frost aspects}

Natural factors and the age of the human presence are the fundamental component in the structuring and functioning of the Rifain landscape. The historic urbanization that goes back to the first Mediterranean civilizations are the essential constituents of the cultural landscape of the Rif area. The predominance of the rural population occupying most of the mountains in the Central Rif study area (more than $90 \%$ of the provinces of Chafchaouen, Taounate and Al Hociema) reflects very marked differences across the country.

In the Oudka mountain (Taouante Province), in the study area, 1994 and 2014 general population census indicate that the population and the number of families have undergone a significant evolution over the last few decades. This population grew from 7447 in 1994 to 8494 in 2014 , an increase of $14.5 \%$ over this period. During the same period, the number of households has risen from 1312 in 1994 to 1888 in 2014, an increase of 29 households per 
year. This evolution has materialized by the fragmentation of agricultural properties (Table 2).

\begin{tabular}{cllll}
\multirow{2}{*}{ Size in hectare } & \multicolumn{2}{c}{ Surface } & \multicolumn{2}{c}{ Exploitations } \\
\cline { 2 - 5 } & ha & $\%$ & Number & $\%$ \\
\hline$<1$ & 663,92 & 8,7 & 1564 & 26,79 \\
\hline $\mathbf{1 - 2}$ & 1686,5 & 22,1 & 1482 & 36,3 \\
\hline $\mathbf{2 - 3}$ & 3258,5 & 42,7 & 1213 & 29,71 \\
\hline $\mathbf{3 - 4}$ & 1533,9 & 20,1 & 265 & 6,49 \\
\hline $\mathbf{P 4}$ & 488,4 & 6,4 & 29 & 0,71 \\
\hline Total & 7631 & 100 & 4083 & 100
\end{tabular}

Table 2 - The distribution of exploitations by size in ha

(Census of Agriculture in 1996, Morocco).

The cultivation and fire, which were once a common and locally planned practice in the traditional system of long rotational crops, is replaced by permanent clearing. The different natural ecosystems are also impoverished by over-grazing mainly goat (Fig. 6), and by the overexploitation of plant biomass for different energy and commercial needs.

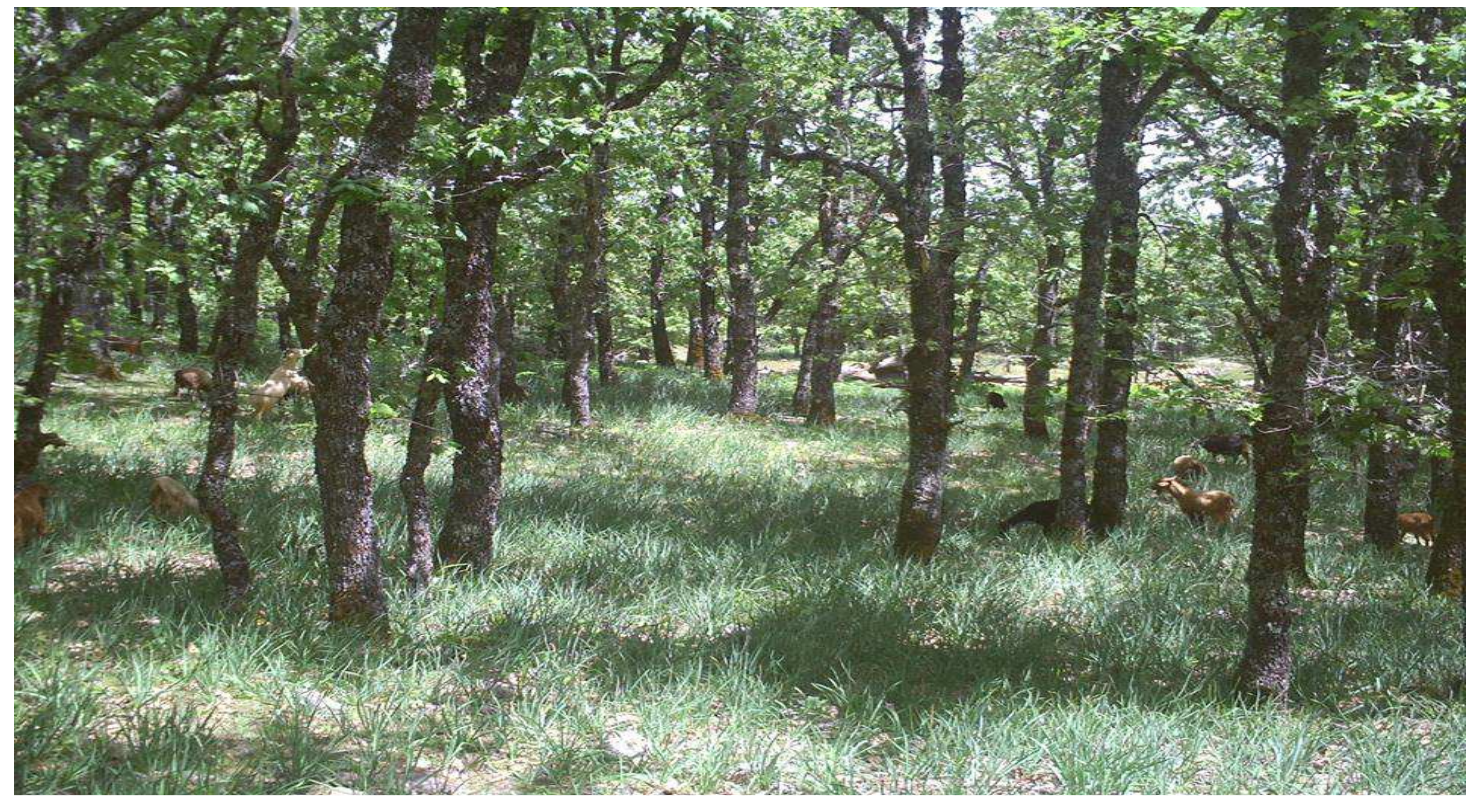

Figure 6 - Degradation the forest of Oudka by over-grazing in Rif mountain area.

(Situation of June 2016)

The present transformation is the result of conflicts between cultural and ecological dimensions against the socio-economic and institutional phenomena provoked since the 
beginning of the twentieth century, especially with the arrival of the cultivation of Cannabis (Fig. 7).

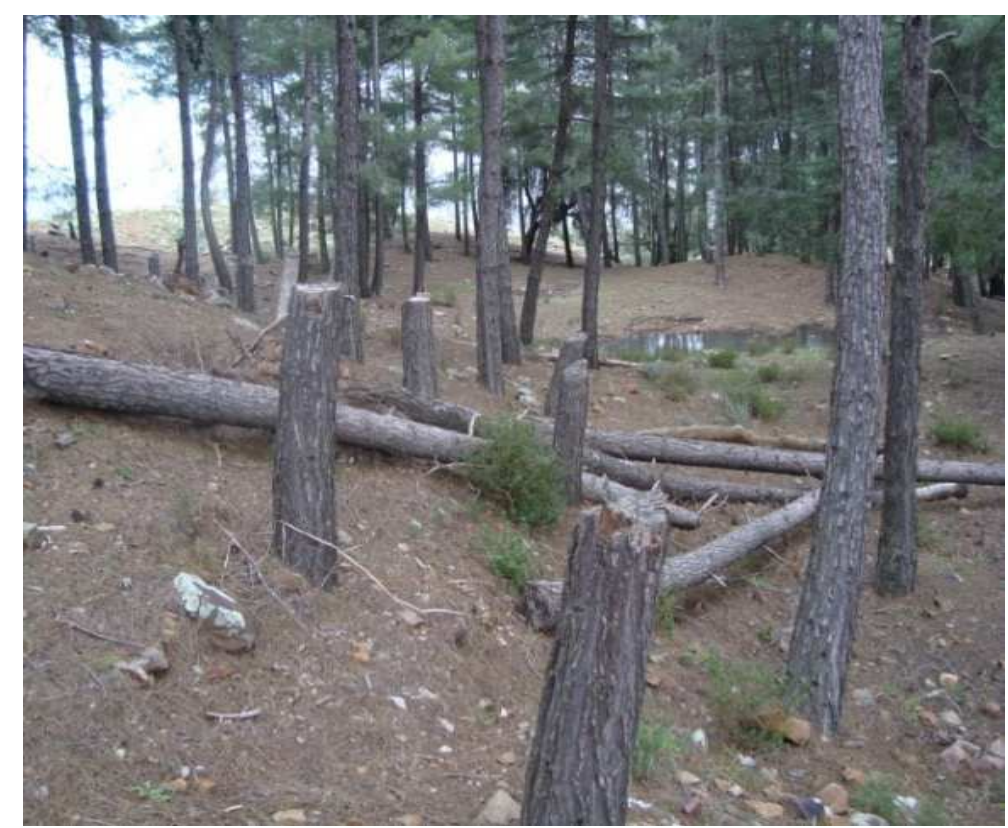

Figure 7 - Clearing of the forest area at the Oudka forest in Central Rif mountains. (Situation of August 2016)

Clearing for the new cultivation of Cannabis becomes a huge problem in the whole area in northern Morocco (fig. 8 and 9), which extended to almost all the slopes that were occupied by different plant species and ecosystems.

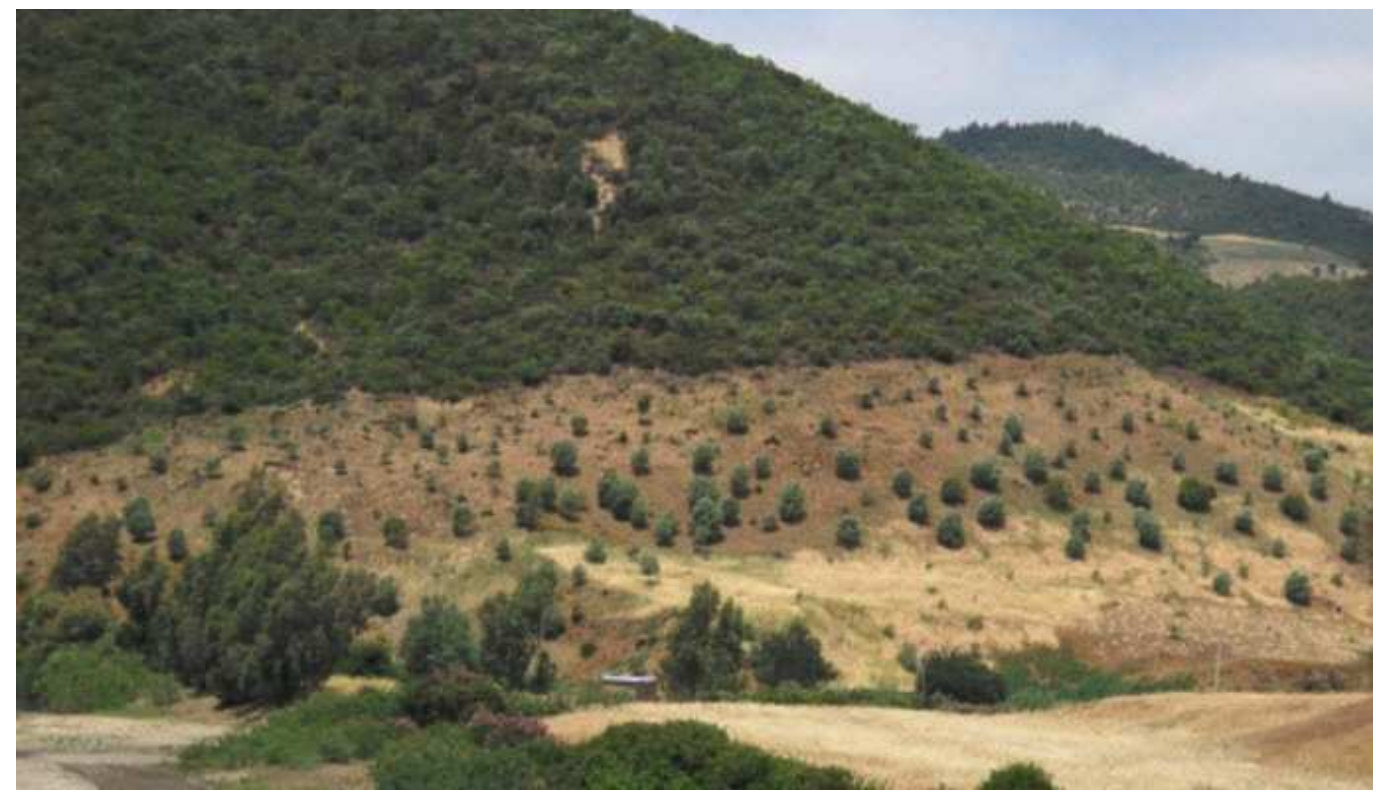

Figure 8 - Forest clearing for the establishment of the cultivation of Cannabis. (Situation of July 2016) 


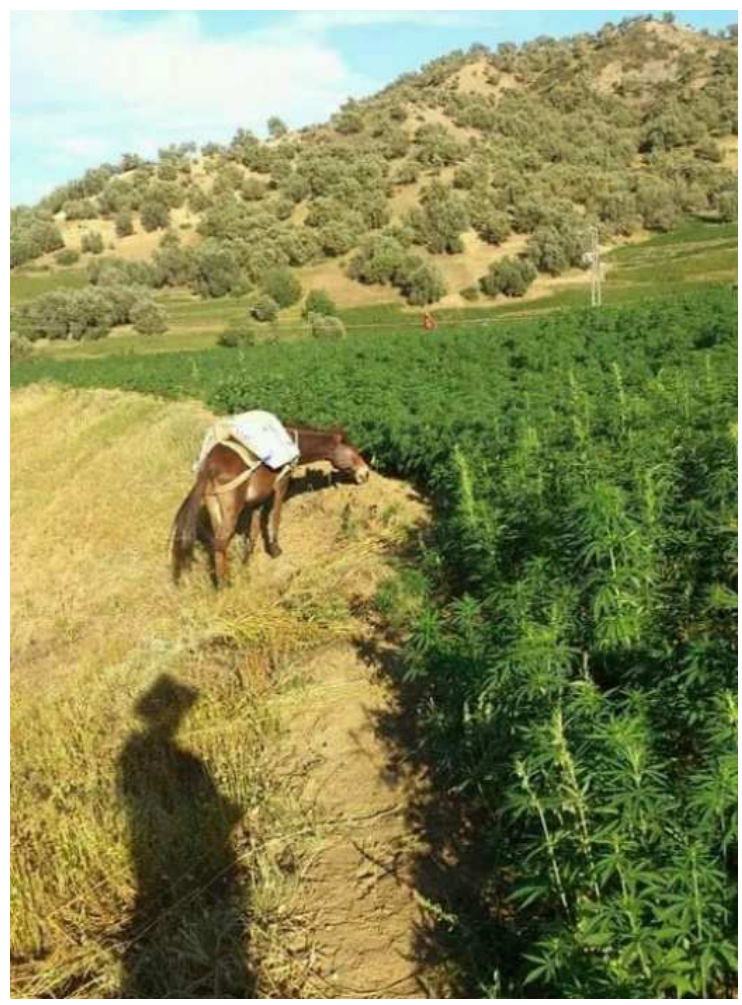

Figure 9 - The appearance of Cannabis cultivation on the slope of the Rif mountains. (Situation of May 2016)

A large part of these occupied lands was foresting that farmers cut down to grow cannabis despite this being an illegal activity since 1974. The data available demonstrates, despite all the efforts and interventions by the authorities and foresters (Fig. 10), the problem of forest fires is persisting. The failure of the administrative mode of management and the too high price of the legality of the cultivation of Cannabis (Salahdine, M. et al., 1991), by its great economic profitability, it ensures satisfactory incomes to the local populations allowing them to subsist, while exposing the region to the different types of environmental resources degradation. 


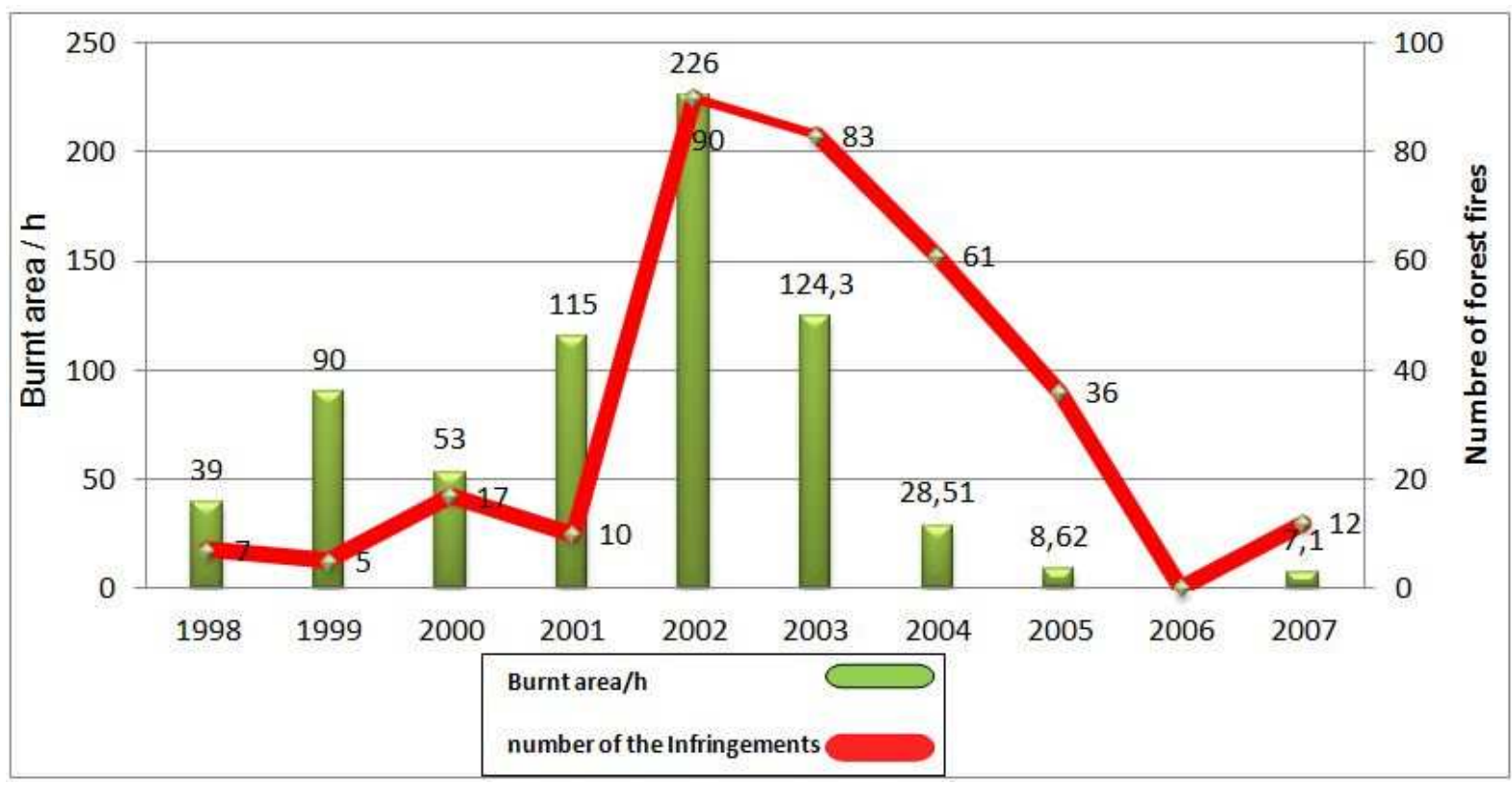

Figure 10 - The evolution of the burnt area and the number of infringements in Oudka forest in Rif mountain zone (HCEFLCD, statistics, Morocco).

\section{Outcomes and discussions}

The regression follow-up of the Oudka forest based on two missions of aerial photos of 1986 and 2016. The methodology adopted in this study allows to follow the evolution of forest stands in the Oudka mountain massif for both spatially and temporally, through the superimposition of maps to evaluate the dynamics of forest environments during the period between 1986 and 2016 (Fig. 11 and 12).

The distribution of forest species and the delimitation is estimated visually using a charter (Godron, M. and Forman, R., 1983). The characteristics of the vegetation mat on aerial photographs largely reflect global ecological aspects. Indeed, forests appear on aerial photographs in dark colours and the shades of this colour from dark to light indicate the changes in age of species, type and density. 


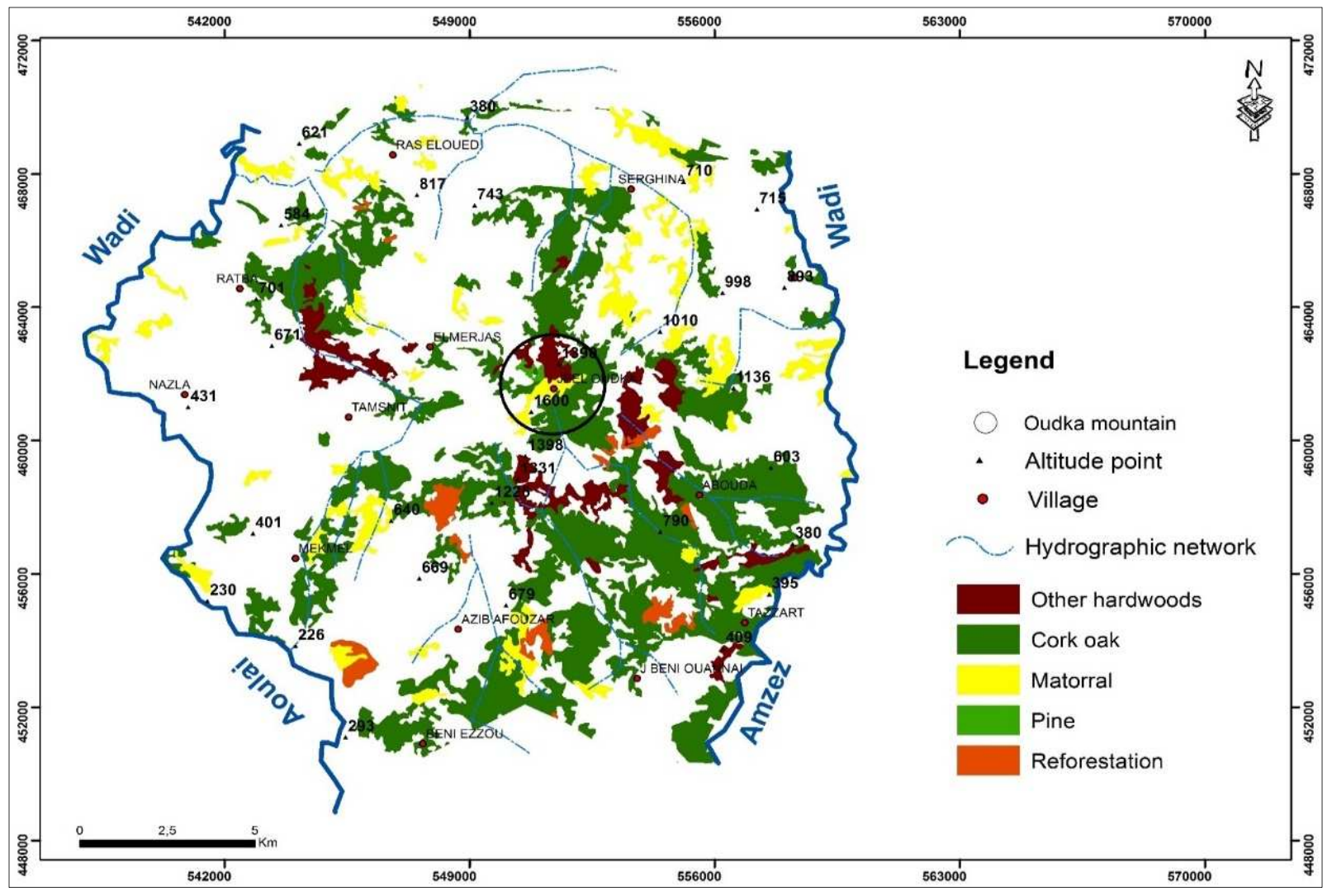

Figure 11 - Forest cover of the Oudka mountain massif in 1986

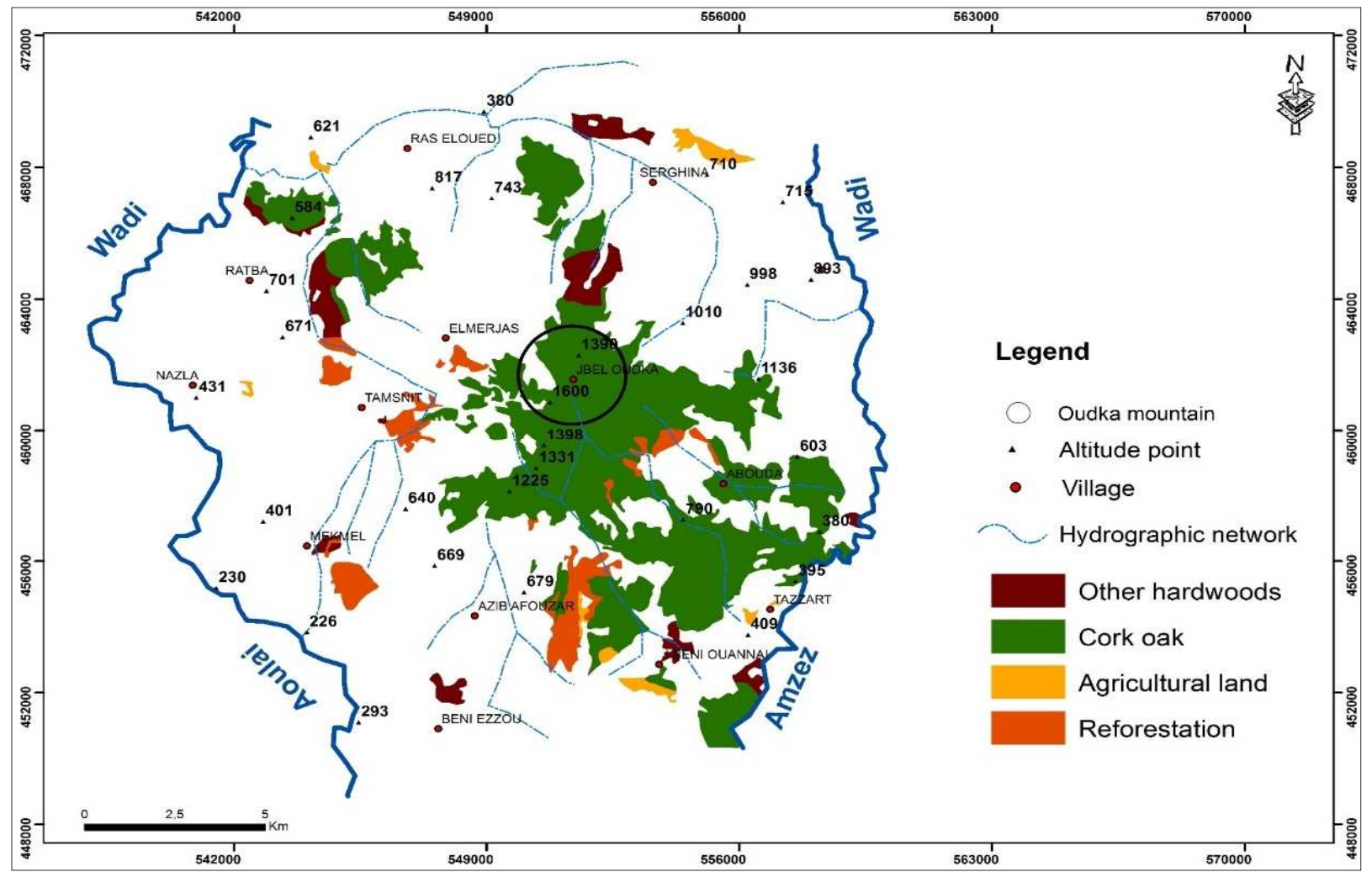

Figure 12 - Forest cover of the Oudka mountain massif in 2016. 
The cartographic study of the space-time evolution showed the increase in demand caused the need for cultivable land for the cultivation of Cannabis. The result is the extension of the production to the neighbouring zones, a dazzling rise in the number of hectares of forest and the species they harbour. In the last 30 years, the forest area of the Oudka massif has deteriorated in terms of areas and species (Table 3Table ).

\begin{tabular}{|lcccc|} 
Forest species & $\begin{array}{c}\text { Area in ha } \\
\text { in } \mathbf{1 9 8 6}\end{array}$ & $\begin{array}{c}\text { Area in ha } \\
\text { in } \mathbf{2 0 1 6}\end{array}$ & $\begin{array}{c}\text { Evolution 1986- } \\
\mathbf{2 0 1 6}\end{array}$ & $\begin{array}{c}\text { Interval in 30 years } \\
\mathbf{1 9 8 6 - 2 0 1 6} \text { in \% }\end{array}$ \\
\hline Other hardwoods & 1240 & 639 & $\mathbf{6 0 1}$ & $<48.46$ \\
\hline Cork oak & 7860 & 6321 & $\mathbf{1 5 3 9}$ & $<19.58$ \\
\hline Reforestation & 411 & 795 & $\mathbf{3 8 4}$ & $>48.30$ \\
\hline Pine & 23 & 00 & $\mathbf{2 3}$ & $<100$ \\
\hline Matorral & 1762 & 00 & $\mathbf{1 7 6 2}$ & $<100$ \\
\hline Agriculture land & 00 & 873 & $\mathbf{8 7 3}$ & $>100$ \\
\hline
\end{tabular}

Table 3 - Forest degradation in Oudka mountain massif between 1986 and 2016.

These large-scale clearing operations lead to disastrous ecological consequences in the central Rif. The most apparent phenomenon is the destruction of soils through erosion. This situation aggravates by the Cannabis agriculture, in 2000, the statistics of the Ministry of Agriculture highlight under the name "industrial culture", the following data: in the Province of Al Hoceima: 37650 hectares, Province of Chefchaouen: 35760 hectares Province of and in Larache: 11750 hectares.

\section{Alternative planning perspective}

Due to the complexity of the problem of forest natural resources degradation and the interaction of several factors which result different aspects of degradation, many projects have been established to integrate all fragility components to manage the natural resource degradation aspects In the Rif area.

The government of Morocco was concerned about the economic and social deterioration of $1,800,000$ ha in northern region, caused by severe soil erosion, intense, population growth and archaic agricultural methods, because of this situation. In 1960, it requested the 
assistance of the FAO to deal with this complicated and multi-dimension problem. In 1961, it was devoted to the general study of the Rif. In 1964, a report and a series of recommendations were proposed to the Moroccan Government, including a 25-year restoration program. The contribution of the special fund amounted to US $\$ 725,000$ and that of Morocco to the equivalent of about $\$ 1,400,000$ (Roose, E. and Sabir, M., 2002).

The DERRO program (Economic Development of the Western Rif Region), was one of the first projects directly targeting natural resources. It was launched in 1965 and reframed in 1968. It proposed to contribute to the rural development of the Rif area and to control the risk of erosion that threatens this zone. The actions taken under this project included fruit plantations, land improvement works, improvement of herd management, opening of runways, development of springs and erosion control.

scheduled for a period of 25 years, was piloted by the Ministry of Interior. Its intervention was to transform cereal-to-livestock production systems into systems where arboriculture and forage-based livestock farming will become dominant (Fig. 13). The project carried out erosion control work on threatened slopes and worked to reduce the area planted to the benefit of arboriculture, fodder crops and managed ranges (Roose, E. and Sabir, M., 2002).

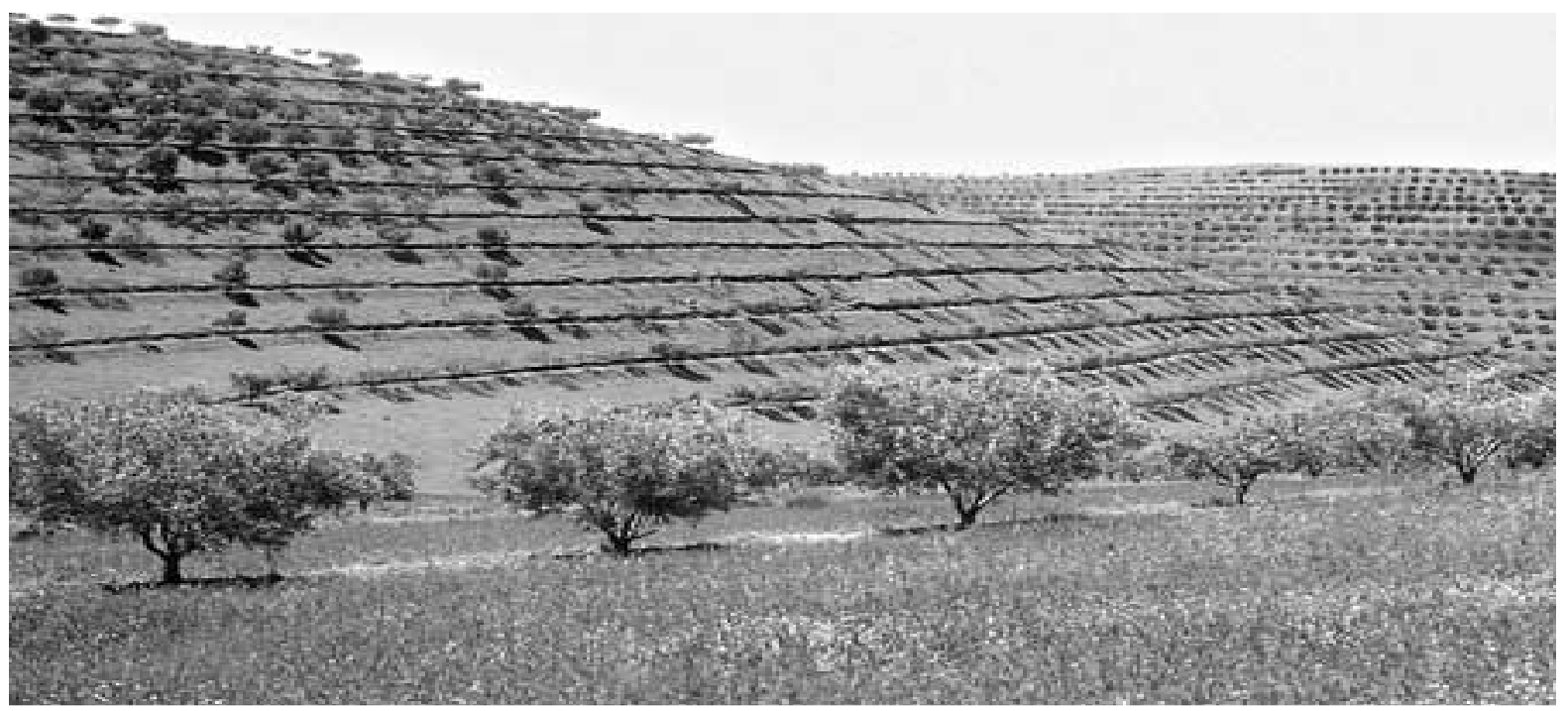

Figure 13 - Bench technique established within DERRO project in Morocco in the 70's, (Bellefontaine, R. et al., 2003).

The first actions were part of the DERRO project, which focused on the problems of degradation, with dramatic extent of erosion in Rif area. It is in this context that a new technique, in this case the bench, has been introduced in the Rif area. The most important public authority in the field of erosion control is the bench, a small terrace that tears the 
slope horizontally at regular distances of $15 \mathrm{~m}$ or $20 \mathrm{~m}$. Its purpose is to intercept runoff and prevent it from eroding, many hectares have been treated by this technique, mainly accompanied by fruit trees, especially olives, and sometimes forests.

This method has been generalized over a very large part of the Rif area, and has contributed to some very eroded and steep slopes to curb soil erosion and degradation. This initiative since the 1965s had some difficulties, and each time the authorities return to the same site for maintenance, or for revegetation after the disappearance of the plants that planted beforehand (Fig. 14), in spite of the surveillance established by the state for the areas covered by the project.

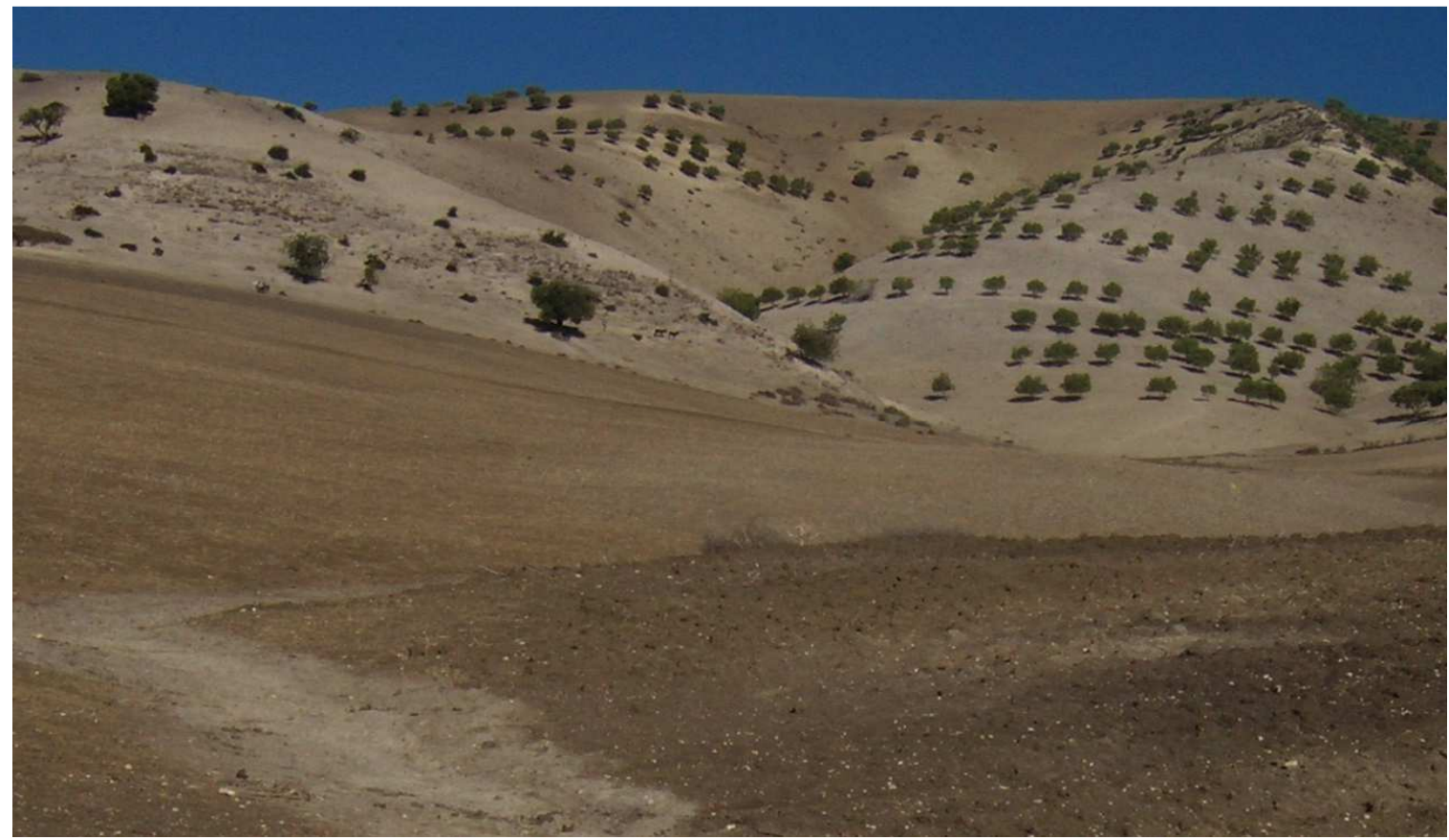

Figure 14 - The failure of the establishment of the benches on steep slopes in Klef hills in Prerif, (Situation of September 2015).

\section{Conclusion}

The accelerated degradation of forest resources in the Rif region of northern Morocco is a major constraint to socio-economic development in this area. The projects set up based on sectoral approaches have met with great failure. Almost $50 \%$ of the forest have been lost as was the case of Jbel Oudka between 1986 and 2016. 
Only a comprehensive development plan for the Rif, based on a participatory approach involving local populations, is likely to curb the degradation of forests, and park the soils and dams retainers in advance, without the populations are hard hit by the reduction or the eradication of cannabis, but we must be aware that a considerable financial effort on the part of Europe, the United Nation and Moroccan government, were not able to fix all the farmers on their land who currently live in the Rif. From 1961 to the present-day programs and projects are still existing in the Rif zone without results.

The global changes including clearing and the new illegal agricultures of the fragile Rif lands contribute to the depletion of the soil by intensive crops without compensation by inputs of organic matter and nutrients, overgrazing, overexploitation of the forest resources. This situation is aggravated at the moment by the effect of climate change, which leads to the acceleration of immigration flows and the abundance of highly degraded lands.

\section{Acknowledgment}

We would like to give special thanks and appreciation to the water and forestry staff for the fruitful comments and discussions that led to the improvement of this work. Anonymous reviewers are thanked for their comments and suggestions.

This work is carried out within the framework of the project Reclimplan within the Ibn Khaldoun program for scientific research in Morocco, in partnership with CEGOT-UP in Portugal, the Institute for Geosciences and Geography at MLU in Halle in Germany, coordinated by the UM5R in Rabat, Morocco

\section{References}

ANDRIEUX, Jean. (1971). La Structure Du Rif Central: Notes Serv.Géol. . Maroc 235 1-155

ASEBRIY, Lahcen, de Luca, Patrick, Bourgois, Jacques;Chotin, Pierre. (1987). Resédimentations d'âge sénonien dans le Rif central (Maroc): conséquences sur les divisions paléogéographiques et structurales de la chaîne. Journal of African Earth Sciences (1983), 6 (1), 9-17. 
BELLEFONTAINE, Ronald, MHIRIT, Omar;ET-TOBI, Mohamed. (2003). Arbres hors forêt: extension et précision du concept. available online on, http://www.fao.org/docrep/005/Y2328F/y2328f21.htm, Checked on May 10, 2017.

BENYAICH, A. (1991). Evolution tectono-sédimentaire du Rif externe centro-occidental (régions de M'sila et Ouezzane, Maroc): La marge africaine du Jurassique au Crétacé: Les bassins néogènes d'avant-fosse. Thèse Doctorat d'État, Univ. Pau, $308 \mathrm{p}$

BENZAGGAGH, Mohamed, MOKHTARI, Abdelkader, ROSSI, Philippe, MICHARD, André, EL MAZ, Abdelkhader, CHALOUAN, Ahmed, . . RJIMATI, Ech-Cherki. (2014). Oceanic units in the core of the External Rif (Morocco): Intramargin hiatus or South-Tethyan remnants? Journal of Geodynamics, 77, 4-21.

DE LAMOTTE, D FRIZON, ANDRIEUX, JEAN;GUEZOU, JEAN-CLAUDE. (1991). Cinematique des chevauchements neogenes dans l'Arc betico-rifain; discussion sur les modeles geodynamiques. Bulletin de la Société géologique de France, 162 (4), 611-626.

EL-FENGOUR, Abdelhak. (2016). Landslide susceptibility assessment in the Amzaz Valley, Central Rif, Morocco. (Master dissertation), University of Porto. Portugal.

EL MOTAKI, Hanifa. (2017). Natural resources: assessment, management and sustainable conservation in Central Rif mountains, Morocco. (Master dissertation), University of Porto. Portugal.

GODRON, M; FORMAN, RTT. (1983). Landscape modification and changing ecological characteristics. In: Mooney HA, Godron M (eds), Disturbance and ecosystems: components of response. Springer-Verlag, New York, pp. 12-28

MAURER, Gérard. (1968). Les montagnes du Rif central : étude géomorphologique (Vol. 14): Rabat, Maroc: Institut scientifique chérifien, Ministère de l'éducation nationale et des baux-arts, Royaume du Maroc.

QUEZEL, Pierre;MEDAIL, Frédéric. (2003). Ecologie et biogéographie des forêts du bassin méditerranéen. Elsevier, Paris, $592 \mathrm{p}$.

ROOSE, Eric; SABIR, MOHAMED. (2002). Stratégies traditionnelles de conservation de l'eau et des sols dans le bassin méditerranéen: classification en vue d'un usage renouvelé. Bulletin Réseau Érosion, 21, 33-44.

SALAHDINE, Mohamed, EL ABDAIMI, Mohamed;ABDAIMI, A. (1991). L'Emploi invisible au Maghreb: études sur l'économie parallel̀e: Société Marocaine des Éditeurs Réunis, Rabat.

SUTER, G; MATTAUER, R (Cartographer). (1964). Geological map of RIF, area of middle Ourgha, Taounate - Ain Aicha.

WILDI, Walter. (1981). Le Ferrysch: cône de sédimentation détritique en eau profonde à la bordure nord-ouest de l'Afrique au Jurassique moyen à supérieur (Rif externe, Maroc). Eclogae Geologicae Helvetiae, 74 (2), $481-$ 527. 